\title{
Özel Spor İşletmelerinde Çalışan Personelin Genel Sinizm Düzeylerinin İncelenmesi*
}

\author{
Serdar Ceyhun ${ }^{\dagger 1}$, Nedim Malkoç², Nesrin Arslan ${ }^{3}$ \\ ${ }^{1}$ Karabük Üniversitesi, Hasan Doğan Beden Ĕ̆itimi Spor Yüksekokulu \\ ${ }^{2}$ Sağllk Bilimleri Üniversitesi \\ ${ }^{3}$ Karabük Üniversitesi, Safranbolu Meslek Yüksekokulu
}

$\ddot{\mathbf{O} z}$

Küreselleşen dünyada ortaya çıkan kavramlardan biri sinizmdir. Genel sinizm, olaylar karşısında bireylerin olumsuz tutum ve davranışlarını içerir. Bu araştırmanın amacı, özel spor tesislerinde çalışan personelin genel sinizm seviyelerini belirlemektir. Araştırmanın örneklemini İstanbul 'da, özel spor tesislerinde çalışan 305 personel oluşturdu. Çalışmamız 2016 yılı yaz döneminde gerçekleştirildi. Araştırmada, personelin genel sinizm seviyelerini belirlemek için Wrigthsman (1992) tarafindan geliştirilen genel sinizm ölçeği kullanıldı. Ölçeğin genelinin ve alt faktörlerinin güvenirliğini test etmek için Cronbach Alpha güvenilirlik analizi ile değerlendirildi. Genel Sinizm ölçeğinin alt faktörleri ve genelinden elde edilen puanların dağılımlarına ilişkin betimsel istatistikler (ortalama, standart sapma, minimum değer, maksimum değer, çarpıklık ve basıklık) hesaplandı. Çalışanların demografik özelliklerinden medeni durum ve idari görevlerinin olma durumlarına göre genel sinizm sinizm düzeyleri arasındaki farklılığı belirlemek için Independent-Sample t testi analizi kullanıldı. Çalışanların yaş, meslekteki çalışma yılı ve aylık gelir düzeyi ile genel sinizm ölçeğinin alt faktörleri ve geneline ilişkin sinizm seviyeleri arasındaki ilişkiyi incelemek için One-Way ANOVA (Tek yönlü ANOVA) analizi kullanıldı. Çalışmada bilişsel sinizm alt boyutunun sinizm seviyesinin daha yüksek olduğu görüldü Sinizm seviyesinin demografik değişkenlerden; yaş, medeni durum, idari görevde olma durumu, çalışma y1lı ve gelir durumu etkilendiği bulundu. Araştırmanın bulguları dâhilinde öneriler geliştirildi.

\author{
Orijinal Makale \\ Yayın Bilgisi \\ Gönderi Tarihi: 19.11 .2017 \\ Kabul Tarihi: 29.12.2017 \\ Online Yayın Tarihi: 29.12.2017
}

\section{Personnel Working in Special Sport Facilities Investigation of General Cynicism Levels}

\begin{abstract}
Cynicism is a concept that stands out in the globalizing world. General cynicism defines the negative attitudes and behaviours of people towards events and individuals. The aim of this research is to determine general cynicism levels of the personnel working in the private sports facilities. The sample of the research is composed of 305 personnel working in private sports facilities in Istanbul. General cynicism scale developed by Wrigthsman (1992) was used to determine general cynicism levels of the personnel. Cronbach Alpha reliability analysis was used to evaluate the reliability of the subscales and overall scale of the scale. Descriptive statistics (mean, standard deviation, minimum value, maximum value, skewness and kurtosis) were calculated for the sub-factors of general Cynicism scale and the distributions of the scores from the overall scale. The levels of general cynicism related to marital status and the presence of administrative tasks from the demographic characteristics of the employees were analysed by the Independent-Sample $t$ test analysis. One-Way ANOVA (One-way ANOVA) analysis was used to examine the association between organizational cynicism levels and the age, occupational years of work, and monthly income levels of employees. In the study it was seen that the scale of the perceptual cynicism subscale was at a higher level. Moreover, cynicism was found to be influenced by age, marital status, status of being in administrative duty, duration of study.
\end{abstract}

Anahtar kelimeler:

Sinizm,

genel sinizm,

spor işletmeleri, spor 


\section{GíRiş}

Sinizm, geniş boyutlu bir kavram olmasının yanı sıra, felsefe, din, politika, sosyoloji, psikoloji ve yönetim gibi farklı disiplinlerin de konusunu oluşturur. Sinizm (kinizm, sinizm), temeli antik Yunan'a dayanan düşünce akımı ve hayat felsefesidir. Sinizm, "zor beğenen, memnuniyetsiz, olaylara sürekli eleştirel yaklaşan, menfaat düşkünü ve olumsuz düşüncelerle dolu varlıklar" anlamlarına gelmektedir. Ayrıca dürüstlük, adalet ve içtenlik gibi olumlu özelliklerin bireysel menfaatler için terk edilebileceğini savunur (Efilti ve ark., 2008). İnsanların sadece kendi çıarlarını koruduğuna inanan ve herkesi çıkarcı kabul eden bireylere 'sinik'; bu görüşü açıklayan düşünce ise 'sinizm' olarak ifade edilir (Erdost ve ark., 2007). Sinik ve sinizm kavramları en sade anlamıyla kişilerin çevresindekilere ve kurumlara güvenmemesi ve hoşlanmaması, küçük görmesi olarak tanımlanmaktadır (Andersson, 1996; Brandes ve ark., 2008; Peng \& Zhou, 2009). Sinizm, insanların her davranışında mutlaka bir çıkar bulunduğuna inanan ve iyiliğin olmadığına inanan düşünce biçimidir (Erdost ve ark 2007). Leiter ve Schaufeli (1996)'ye göre yeni sinizm kavramı içinde ilgisizlik veya işe olan uzak tutumu yansıtmada vardır. Yapılan bu açıklamalar doğrultusunda sinizm, kişilerin çevresindeki bireyleri ve olayları sürekli eleştiren, karamsar düşünüp memnuniyetsiz olarak nitelendiren bir düşünce akımıdır denilebilir (Efilti ve ark., 2008). Araştırmalarda sinizmin beş dalda sınırlandırıldığı görülmektedir. Bunlar; genel (kişilik) sinizm, çalışan sinizmi, iş (meslek) sinizmi, toplumsal/ kurumsal sinizm ve organizasyonel değişim sinizmidir (Akman, 2013).

\section{Genel Sinizm Kavramı}

Genel (kişilik) sinizm doğuştan gelen, bireylerin düşünce ve davranışlarını negatif olarak içselleştiren sinizm türüdür. Genel sinizmde, kişi insanlara karş̧ düşmanca davranışlarda bulunur. Olumlu davranışları bile sorgular. Genel sinizm bir kişilik özelliğidir ve bireyler bu sinizm türünde olumsuz düşüncelerini kolay kolay değiştirmezler (Abraham, 2000). Genel sinizmin, etik dışı davranışların normal olduğunu savunan bir inanç olduğu da belirtilmiştir (Nair \& Kamalanabhan, 2010). Bu sinizm çeşidi, insan davranışlarını negatif, değişmeyen ve doğuştan gelip istikrarlı olduğuna inanan tek sinizm çeşididir. Birey bu sinizm türünde diğer çalışanları küçük görür ve onlarla arasında zayıf bir bağ kurar (Abraham, 2000). Kısaca genel (kişilik) sinizm bireyin kişiliğinden kaynaklanıp, bireyde sinik tutumların oluşmasına sebep olur (Tokgöz ve Yılmaz, 2008).

Genel sinizm, topluma ve iş de dâhil olmak üzere çeşitli kuruluşlara yönelik olmakta, birey ve bireyin parçası olduğu toplum arasında sözleşme ihlalleri gerçekleştiğinde somutlaşmaktadır (Mısırdalı Yangil ve ark., 2014). Bireyler toplumsal düzen içinde rollerinin farkındadırlar. Aynı zamanda toplumdan beklentileri de bulunmaktadır. Genel sinik bireyin en önemli özelliği, sosyal ve ekonomik kuruluşlara karşı yabancılaşarak firsatçı ve kendi çıkarlarına hizmet eden bir kişiliğe bürünmesidir (Nair \& Kamalanabhan, 2010).

Spor işletmelerinin varlık nedeni, temelde, müşterilerin spor konusundaki beklenti ve ihtiyaçlarını karşılayacak tarzda, en uygun fiyat ve zamanda hizmet tasarlayıp sunmaktır (İmamoğlu, 1998). Bu anlayışla yola çıkıldığında; aslında müşteri beklentilerini karşılayacak en önemli etkeninde işletmedeki çalı̧̧anlar olduğu söylenebilir. Spor işletmeleri de diğer işletmeler gibi birçok insanın beraberce çalışmasından meydana gelen büyük birer işbirliği 
sistemi niteliği taşıdığından, hizmet verilirken işletmenin her birimindeki görevli elemanların aynı hizmet anlayışıyla hareket etmesi gerekir. Spor işletmelerinin önemli bir özelliği; diğer bazı sektörlerde olduğu gibi yüz yüze ilişkilerin yoğun yaşandığı bir sektör olmasıdır (Ceyhun, 2017). Örgüt ve işletme başarısı açısından konuya yaklaşıldığında her bir çalışanın spor işletmelerinde verimli ve rasyonel işler üretmesi yaptığı işte aynı zamanda ne kadar istekli çalışmasıyla doğru orantılı olacaktır. İşletmedeki sağlıklı bir örgüt ikliminin özellikleri arasında; Kişi ve örgüt arasında bir psikolojik sözleşmenin bulunması, kişilerin işteki ihtiyaç ve beklentilerinin, bireysel farklılıklarının ve özelliklerinin saptanması, çalışma yaşamının kalitesi ve iş tasarımına karşı ilgi gibi maddelerin bulunması (Hocaniyazov, 2008) aslında sinizmin oluşmasını da engelleyen etkenler arasında yer almaktadır.

İşletmeler açısından insanın değerinin ön plana çıkması, yönetim alanında yeni kavramların incelenmesi neticesini de doğurmuştur. $\mathrm{Bu}$ kavramlardan biriside genel sinizmdir. $\mathrm{Bu}$ araştırmanın amacı spor işletmelerinde çalışan personelin genel sinizm düzeylerini belirleyerek, sorunların çözümüne katkı sağlamaktır.

\section{YÖNTEM}

\section{Araştırma Modeli}

Yapılan araştırma; spor işletmelerindeki çalışanların genel sinizm seviyelerini belirlemek ve çalışanların demografik özelliklerine göre genel sinizm seviyeleri arasındaki farklılığı ortaya çıkarmak amacıyla yapılmıştır. Bu amaç bağlamında yapılan araştırma tarama modeli olarak nitelendirilebilir. Tarama modeli; var olan bir durumu olduğu şekli ile betimleyeme çalışan araştırma yaklaşımlarına denir (Karasar, 2009).

\section{Evren ve Örneklem}

Araştırma evrenini İstanbul ilindeki özel spor işletmelerinde çalışan 1476 personel oluşturmaktadır. Araştırmanın evrenini temsil edebilecek örneklem miktarı \%95 güven aralığı veya 0,05 hata miktarı göz önünde bulundurularak kolaylıkla bulunabilen örnekleme yöntemi ile belirlenen 305 personel oluşturmaktadır. Kolaylıkla bulunabilen örnekleme, bir bölge söz konusu değilse, yakın çevrede bulunan ve ulaşılması kolay, elde mevcut ve araştırmaya katılmak isteyen (gönüllü) bireyler üzerinde yapılan örneklemedir (Erkuş, 2013).

Araştırma örneklemi aşağıda yer alan eşitlik kullanılarak hesaplanmıştır:

$$
=\frac{\mathrm{n}_{0}}{1+\frac{\mathrm{n}_{0}}{\mathrm{~N}}}
$$

Sürekli değişkenlerde örneklem büyüklüğü tahmini

Formülde yer alan $n_{0}=\left(t^{2} P Q\right) / d^{2}$ eşitliği ile hesaplanmakta, $p$ ve $q$ anlamlılık değeri 0,05 alındığında, $\mathrm{pq}=0,25$ olacağından ve tabloda karşılık gelen $\mathrm{t}$ değeri 1,96 olduğundan 0,05 anlamlılık düzeyinde $\mathrm{n}_{0}=384,16$ olarak hesaplanmaktadır (Büyüköztürk ve ark., 2012). Araştırmada örneklem hesaplarken formülde $\mathrm{n}_{0}$ yerine konulduğunda; 


$$
=\frac{384,16}{1+\frac{384,16}{1476}}=304.82=305
$$

olarak hesaplanmıştır. Araştırmanın örnekleminde yer alan 305 personelin demografik özelliklerine göre dağılımları Tablo -1'de verilmiştir.

Tablo-1. Spor işletmelerinde çalışanların demografik özelliklerine ilişkin dağılımları

\begin{tabular}{|c|c|c|c|}
\hline Demografik Özellikler & Kategoriler & $\mathbf{N}$ & $\%$ \\
\hline \multirow{7}{*}{ Yaş Düzeyi } & $20-24$ & 48 & 15.7 \\
\hline & $25-30$ & 60 & 19.7 \\
\hline & $31-35$ & 46 & 15.1 \\
\hline & $36-40$ & 42 & 13.8 \\
\hline & $41-45$ & 41 & 13.4 \\
\hline & $46-50$ & 39 & 12.8 \\
\hline & 51 ve Üstü & 29 & 9.5 \\
\hline \multirow{2}{*}{ Medeni Durum } & Evli & 184 & 60.3 \\
\hline & Bekar & 121 & 39.7 \\
\hline \multirow{2}{*}{ İdari Görevinin Olma Durumu } & Evet & 140 & 45.9 \\
\hline & Hayır & 165 & 54.1 \\
\hline \multirow{5}{*}{ Mesleki Çalışma Yılı } & Bir Yildan Daha Az & 30 & 9.8 \\
\hline & $1-5 Y_{11}$ & 96 & 31.5 \\
\hline & 6-10 Y1l & 68 & 22.3 \\
\hline & 11-15 Y1l & 60 & 19.7 \\
\hline & 16 ve Üstü & 51 & 16.7 \\
\hline \multirow{5}{*}{ Aylık Gelir } & $0-1000 \mathrm{TL}$ & 36 & 11.8 \\
\hline & $1001-2000 \mathrm{TL}$ & 79 & 25.9 \\
\hline & 2001-3000 TL & 87 & 28.5 \\
\hline & $3001-4000 \mathrm{TL}$ & 72 & 23.6 \\
\hline & 4001 ve Üstü & 31 & 10.2 \\
\hline Toplam & & 305 & 100.0 \\
\hline
\end{tabular}

Çalışanların yaş düzeylerine göre dağılım incelendiğinde, "20-24" yaş aralığına sahip 48 $(\% 15,7)$ çalışan, "25-30” yaş aralığına sahip 60 (\%19,7) çalışan, “31-35” yaş aralığına sahip 46 $(\% 15,1)$ çalışan, “36-40” yaş aralığına sahip $42(\% 13,8)$ çalışan, “41-45” yaş aralığına sahip 41 $(\% 13,4)$ çalışan, “46-50” yaş aralığına sahip 39 (\%12,8) çalışan ve "51 ve Üstü” yaş aralığına sahip $29(\% 9,5)$ çalışan bulunmaktadır. Çalışanların medeni durumlarına göre dağılımları incelendiğinde, $184(\% 60,3)$ evli ve $121(\% 39,7)$ bekardır. İdari görevinin olma durumlarına göre dağılımları incelendiğinde, idari görevi olan $140(\% 45,9)$ çalışan ve idari görevi olmayan $165(\% 54,1)$ çalışan bulunmaktadır. Mesleki çalışma yıllarına göre dağılımları incelendiğinde, bir yıldan daha az çalışan 30 (\%9,8), "1-5 Yıl”" mesleki çalışma yılına sahip 96 (\%31,5) çalışan, "6-10 Yı1” mesleki çalışma yılına sahip 68 (\%22,3) çalışan, “11,15 Y11” mesleki çalışma yılına sahip $60(\% 19,7)$ çalışan ve "16 ve Üstü Yıl” mesleki çalışma yılına sahip $51(\% 16,7)$ çalışan 
bulunmaktadır. Çalışanların aylık gelir düzeylerine göre dağılımları incelendiğinde, "0-1000 TL" gelir düzeyine sahip $36(\% 11,8)$ çalışan, "1001-2000 TL” gelir düzeyine sahip $79(\% 25,9)$ çalışan, "2001-3000 TL” gelir düzeyine sahip 87 (\%28,5) çalışan, “3001-4000 TL” gelir düzeyine sahip $72(\% 23,6)$ çalışan ve "4001 ve Üstü TL" gelir düzeyine sahip $31(\% 10,2)$ çalışan bulunmaktadır. Toplamda 305 (\%100) personel çalışmaya katılmıştır.

\section{Veri Toplama Araçları}

Araştırma verileri sosyo-demografik verilerden oluşan anket formu ve genel sinizm Wrightsman'ın 1992'de geliştirilen Arslan (2012) tarafından Türkçe'ye uyarlanan 3 alt boyut 10 maddeden oluşan ölçek kullanılmıştır. Ölçek daha önce Mısırdalı Yangil, Baş ve Aygün (2014) tarafından yıldızlı oteller içerisinde çalışan personele uygulama yapılarak genel sinizm düzeylerini ölçmek için 10 maddelik taslak form uygulanmıştır. Geçerlik için yapılan açıklayıcı faktör analizi sonucunda bilişsel boyuta yönelik 3 madde davranışsal boyuta yönelik 4 madde ve duyuşsal boyuta yönelik 3 madde aynı faktör içerisinde ilişki gösterdiğinden 3 faktörlü genel sinizm ölçeği ortaya çıkmıştır. Bu 3 faktör genel sinizmin \%67'sini açıklamaktadır.

Spor işletmelerinde çalışan 305 katılımcı grubun üzerinden yapılan araştırmada yukarıda tanımlanan yapının doğrulanması için doğrulayıcı faktör analizi ve güvenirlik analizleri yapılmıştır. Örneklem özelliğinin değişmesinden dolayı daha önceden tanımlanan yapının yeni örneklem grubunda doğrulanıp doğrulanmadığı Doğrulayıcı Faktör Analizi (DFA) ile incelenmiştir. Genel sinizm ölçeğinin 3 faktörlü 10 maddelik yapısına uygulanan DFA ile yap1 geçerliğinin temsili olarak uygulanmıştır. İlk olarak DFA analizinde anlamlı olmayan $\mathrm{t}$ değerine sahip bir madde bulunduğu bu madde davranış alt faktöründe yer alan 10. madde olduğu görülmektedir. Bu madde ölçekten çıkarılarak DFA modeli tekrar kurulmuştur. 9 madde ile kurulan DFA modeline ait maddelerin t uyum istatistikleri incelendiğinde uyumsuz hiçbir maddenin olmadığı sonucuna ulaşılmıştır. Ölçekte yer alan maddelerin oluşturduğu faktörler ile uyumlarının doğrulandığı görülmektedir. Bu bağlamda bu uyuma ilişkin ortaya çıkan DFA modeli Şekil 1'de görülmektedir. Relative Multivariate Kurtosis $=1.106>1.00$ olduğundan dolayı çok değişkenli normallik varsayımını sağlamadığı ve bu sebeple Maksimum Likelihood (ML) parametre kestirim yöntemi yerine Robust Maksimum Likelihood (RML) parametre kestirim yöntemi kullanılmıştır. Genel sinizm ölçeğine ait uyum indeks değerleri Tablo-2'de görülmektedir.

Tablo 2. Genel sinizm ölçeğinin geçerlik çalışmasına ilişkin uyum indeks değerleri

\begin{tabular}{lllllll}
\hline \multirow{2}{*}{ Uyum İndeks } & $\chi^{2 /(\mathrm{df})}$ & RMSEA & SRMR & TLI/NNFI & CFI & NFI \\
\cline { 2 - 6 } & $42.36 /(23)=1.84$ & 0.070 & 0.062 & 0.96 & 0.97 & 0.94 \\
\hline
\end{tabular}

Tablo 2'te genel sinizm ölçeğine ait kurulan ölçme modeline ilişkin uyum indeks değerleri incelenmiştir. $0 \leq \chi 2 /(\mathrm{df})=1.84 \leq 2$ kritik değerleri aralığında olduğundan iyi uyum sergilediği görülmektedir. RMSEA ve SRMR değerlerine bakıldığında 0.08 kritik değerinden küçük olması, kabul edilebilir uyum indeksine sahip olduğunu gösterir (Schermelleh-Engel, Moosbrugger \& Müller, 2003). CFI değerinin iyi uyum indeks değerine sahip olduğu ve NFI ve TLI/NNFI değerlerinin kabul edilebilir uyum indeksine sahip olduğu görülmektedir ( $\mathrm{S}$ Schermelleh-Engel, Moosbrugger \& Müller, 2003). 
Uyum indeks değerleri incelendiğinde genel sinizm ölçeğinin alt faktörleri ve geneli ile kurulan ölçme modelinin doğrulandığı görülmektedir. Genel sinizm ölçeğine ait 1 . Düzey 3 faktörlü DFA modeli Şekil 1'de görülmektedir.

Şekil 1 Genel sinizm ölçeğine ait 1. düzey 3 faktörlü dfa modeli

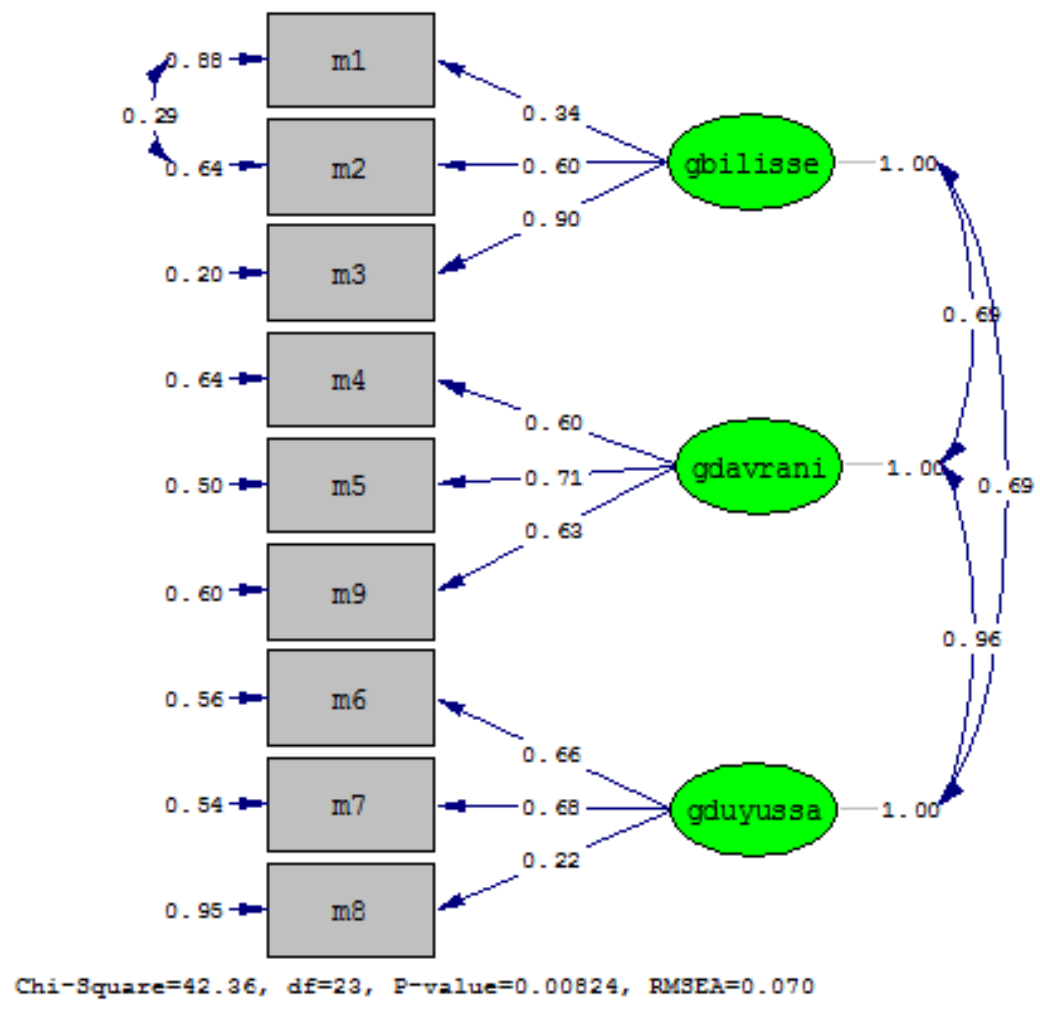

Ölçeğin güvenirliğinin belirlenmesinde iç tutarlılık katsayısı olan Cronbach alpha hesaplanmıştır. Bilişsel sinizm alt faktörüne ilişkin güvenirlik katsayısı ,70 olduğu, davranışsal sinizm alt faktörüne ilişkin güvenirlik katsayıs1 ,70 olduğu, duyuşsal sinizm alt faktörüne ilişkin güvenirlik katsayısı ,74 olduğu ve Genel Sinizm Ölçeğinin geneline ilişkin güvenirlik katsayısı ,83 olduğu görülmüştür. Özdamar'a (1999) göre, Cronbach Alpha güvenirlik değerinin 0,60 ile 0,80 arasında olması kabul edilebilir derecede güvenilir olduğu ve 0,80-0,90 arasında olması yüksek düzeyde güvenilir olduğunu ifade etmektedir. Bu bağlamda alt faktörlere ait güvenirlik katsayılarının kabul edilebilir güvenirlik düzeyine sahip olduğu ve ölçeğin geneline ilişkin güvenirlik katsayısının ise yüksek düzeyde güvenirlik katsayısına sahip olduğu görülmektedir (Tablo 3).

Tablo 3. Genel sinizm ölçeğinin geneli ve alt faktörlerine ait cronbach alpha güvenirlik sonuçları

\begin{tabular}{lcccc}
\hline & Bilişsel Sinizm & Davranışsal Sinizm & Duyuşsal Sinizm & Genel Sinizm \\
\hline Madde Sayısı & 3 & 3 & 3 & 9 \\
\hline Cronbach $\alpha$ & .70 & .70 & .74 & .83 \\
\hline
\end{tabular}




\section{Verilerin Analizi}

Ölçeğin tekrardan yeni katılımcı grubunda doğrulanma durumunu ortaya çıkarmak için birinci düzey 3 faktörlü doğrulayıcı faktör analizi (DFA) LISREL paket programı kullanılarak yapılmıştır. Ki-kare istatistiğine, hata indekslerine (RMSEA, SRMR), uyum indekslerine (NFI, NNFI, CFI) değerlerine bakılarak ölçme modelinin doğrulanma durumuna ilişkin karara varılmıştır. Ölçeğin alt faktörleri ve geneline ilişkin güvenirlik katsayısına Cronbach Alpha güvenirlik analizi ile bakılmıştır. Ölçeğin genelinden ve alt faktörlerinden elde edilen puan dağılımlarının normalliğine Kolmogorov-Smirnov $Z$ testi ile ve homojenliğine Levene Homojenlik testi ile bakılmış tüm değerlere ait elde edilen $p$ değerinin kritik değer olan 0,05 değerinden yüksek olduğu ve puan dağılımının normal olduğu, test varyanslarının homojen olduğu sonucuna ulaşılmıştır. Ölçme işleminin eşit aralıklı ölçek düzeyinde ve sürekli olduğu görülmektedir. Yapılan analizler sonucunda parametrik test varsayımlarının sağlandığ görülmektedir. Genel sinizm ölçeğinin alt faktörleri ve genelinden elde edilen puanların dağılımlarına ilişkin betimsel istatistikler (ortalama, standart sapma, minimum değer, maksimum değer, çarpıklık ve basıklık) hesaplanmıştır. Çalışanların demografik özelliklerinden medeni durum ve idari görevlerinin olma durumlarına göre genel sinizm ölçeğinin alt faktörleri ve geneline ilişkin sinizm düzeyleri arasındaki manidar farklılığa Independent-Sample (Bağımsız Örneklem) t testi analizi ile bakılmıştır. Çalışanların yaş, meslekteki çalışma yılı ve aylık gelir düzeylerine göre genel sinizm ölçeğinin alt faktörleri ve geneline ilişkin sinizm düzeyleri arasındaki manidar farklılığa One-Way ANOVA (Tek Yönlü Varyans) analizi ile bakılmıştır.

\section{BULGULAR}

Spor işletmelerinde çalışanların genel sinizm seviyelerine ilişkin bilgiler Tablo-4' te verilmiştir.

Tablo - 4. Çalışanların genel sinizm ölçeğinin geneli ve alt faktörlerine ait seviyelerine ilişkin betimsel istatistikler

\begin{tabular}{llllllll}
\hline Alt Boyutlar & N & Minimum & Maximum & $\bar{X}$ & S & Çarpıklık & Basıklık \\
\hline Bilişsel Sinizm & 305 & 5.00 & 15.00 & 10.49 & 2.45 & -.12 & -.72 \\
Davranışsal Sinizm & 305 & 3.00 & 15.00 & 9.70 & 2.68 & -.20 & -.33 \\
Duyuşsal Sinizm & 305 & 3.00 & 15.00 & 10.07 & 2.75 & -.16 & -.60 \\
Genel Sinizm Seviyesi & 305 & 14.00 & 45.00 & 30.26 & 6.38 & -.06 & -.56 \\
\hline
\end{tabular}

Genel sinizm ölçeğinin geneli ve alt faktörlerine ilişkin seviyelerinin dağılımının incelendiği görülmektedir. "Bilişsel Sinizm" boyutunda çalışanların sinizm seviyeleri $\bar{X}=10,49(\mathrm{~S}=2,45)$ ortalamaya sahip olduğu görülmektedir. Çalışanların bilişsel sinizm seviyelerinin -,12 çarpıklık değeri ile ortalamanın üstünde bir seviyeye sahip oldukları görülmektedir. "Davranışsal Sinizm" boyutunda çalışanların sinizm seviyeleri $\bar{X}=9,70(\mathrm{~S}=2,68)$ ortalamaya sahip olduğu görülmektedir. Çalışanların davranışsal sinizm seviyelerinin -,20 çarpıklık değeri ile ortalamanın üstünde bir seviyeye sahip oldukları görülmektedir. "Duyuşsal Sinizm” boyutunda çalışanların sinizm seviyeleri $\bar{X}=10,07(\mathrm{~S}=2,75)$ ortalamaya sahip olduğu görülmektedir. 
Çalışanların duyuşsal sinizm seviyelerinin -,16 çarpıklık değeri ile ortalamanın üstünde bir seviyeye sahip oldukları görülmektedir. Genel sinizm ölçeğinin geneline bakıldığında çalışanların seviyeleri $\bar{X}=30,26(\mathrm{~S}=6,38)$ ortalamaya sahip olduğu görülmektedir. Çalışanların genel sinizm seviyelerinin -,06 çarpıklık değeri ile ortalamanın biraz üzerinde bir seviyeye sahip olduğu görülmektedir.

Spor işletmelerinde çalışanların yaşlarına göre genel sinizm seviyeleri Tablo - 5' te verilmiştir.

Tablo 5. Çalışanların yaşlarına göre genel sinizm ölçeğinin geneli ve alt faktörlerine ilişkin sinizm seviyeleri

\begin{tabular}{|c|c|c|c|c|c|c|c|}
\hline Alt boyutlar & Yaş & $\mathbf{N}$ & $\bar{X}$ & $\mathbf{S}$ & $F(6-298)$ & p & \\
\hline \multirow{7}{*}{ Bilişsel Sinizm } & $20-24$ & 48 & 11.98 & 1.73 & \multirow{7}{*}{4.00} & \multirow{7}{*}{$.001 *$} & \multirow{7}{*}{$\begin{array}{c}\text { Post Hoc (Tukey) } \\
1>2, \\
1>3, \\
1>4, \\
1>5, \\
1>6, \\
1>7\end{array}$} \\
\hline & $25-30$ & 60 & 10.37 & 2.31 & & & \\
\hline & $31-35$ & 46 & 10.04 & 2.29 & & & \\
\hline & $36-40$ & 42 & 10.36 & 2.51 & & & \\
\hline & $41-45$ & 41 & 10.27 & 2.36 & & & \\
\hline & $46-50$ & 39 & 10.26 & 2.49 & & & \\
\hline & 51 ve Üstü & 29 & 9.79 & 3.13 & & & \\
\hline \multirow{7}{*}{$\begin{array}{l}\text { Davranışsal } \\
\text { Sinizm }\end{array}$} & $20-24$ & 48 & 9.98 & 2.69 & \multirow{7}{*}{.68} & \multirow{7}{*}{.663} & \\
\hline & $25-30$ & 60 & 9.85 & 2.26 & & & \\
\hline & $31-35$ & 46 & 9.93 & 2.45 & & & \\
\hline & $36-40$ & 42 & 9.88 & 2.68 & & & \\
\hline & $41-45$ & 41 & 9.27 & 3.54 & & & \\
\hline & $46-50$ & 39 & 9.64 & 2.58 & & & \\
\hline & 51 ve Üstü & 29 & 9.03 & 2.60 & & & \\
\hline \multirow{7}{*}{ Duyuşsal Sinizm } & $20-24$ & 48 & 11.06 & 2.34 & \multirow{7}{*}{2.53} & \multirow{7}{*}{$.021 *$} & \multirow{7}{*}{$\begin{array}{l}1>5 \\
1>7\end{array}$} \\
\hline & $25-30$ & 60 & 10.27 & 2.66 & & & \\
\hline & $31-35$ & 46 & 10.07 & 3.06 & & & \\
\hline & $36-40$ & 42 & 9.50 & 2.30 & & & \\
\hline & $41-45$ & 41 & 9.37 & 3.10 & & & \\
\hline & $46-50$ & 39 & 10.51 & 2.71 & & & \\
\hline & 51 ve Üstü & 29 & 9.24 & 2.72 & & & \\
\hline \multirow{7}{*}{$\begin{array}{l}\text { Genel Sinizm } \\
\text { Seviyesi }\end{array}$} & $20-24$ & 48 & 33.02 & 5.09 & & & \multirow{7}{*}{$\begin{array}{l}1>5 \\
1>7\end{array}$} \\
\hline & $25-30$ & 60 & 30.48 & 6.24 & & & \\
\hline & $31-35$ & 46 & 30.04 & 6.07 & & & \\
\hline & $36-40$ & 42 & 29.74 & 6.23 & 2.53 & $.021 *$ & \\
\hline & $41-45$ & 41 & 28.90 & 7.58 & & & \\
\hline & $46-50$ & 39 & 30.41 & 6.11 & & & \\
\hline & 51 ve Üstü & 29 & 28.07 & 6.77 & & & \\
\hline
\end{tabular}

**p<,05 Kategoriler: $20-24=1,25-30=2,31-35=3,36-40=4,41-45=5,46-50=6,51$ ve Üstü=7

"Davranışsal Sinizm" alt faktörüne ilişkin çalışanların yaşlarına göre sinizm seviyeleri arasında $\mathrm{F}_{(6-298)}=, 68, \mathrm{p}=, 663>, 05$ 'e göre anlamlı farklılık olmadığ 1 görülmektedir. "Bilişsel Sinizm" alt faktörüne ilişkin çalışanların yaşlarına göre sinizm seviyeleri arasında $F_{(6-298)}=4,00$, p=,001<,05'e göre anlamlı farklılık olduğu görülmektedir. "Duyuşsal Sinizm" alt faktörüne ilişkin çalışanların yaşlarına göre sinizm seviyeleri arasında $F_{(6-298)}=2,53, p=, 026<, 05$ 'e göre anlamlı farklılık olduğu görülmektedir Genel sinizm ölçeğinin geneline ilişkin çalışanların yaşlarına göre sinizm seviyeleri arasında $\mathrm{F}(6-298)=2,53, \mathrm{p}=, 026<, 05$ 'e göre anlamlı farklılık olduğu görülmektedir. Bu anlamlı farklılık, "20-24” yaş düzeyine sahip olan çalışanların genel sinizm seviyelerinin ( $=33,02)$, “41-45” yaş düzeyine sahip olan çalışanların genel sinizm 
seviyelerinden $(=28,90)$ ve "51 ve Üstü” yaş düzeyine sahip olan çalışanların genel sinizm seviyelerinden $(=28,07)$ daha yüksek olmasından kaynaklanmaktadır.

Spor işletmelerinde çalışanların medeni durumlarına göre genel sinizm seviyeleri Tablo - 6’ da verilmiştir.

Tablo 6. Çalışanların medeni durumlarına göre genel sinizm ölçeğinin geneli ve alt faktörlerine ilişkin sinizm seviyeleri arasındaki farklılığa ait ındependent-sample (bağımsız örneklem) t-testi sonuçları

\begin{tabular}{|c|c|c|c|c|c|c|c|}
\hline Alt boyutlar & Medeni Durum & $\mathbf{N}$ & $\bar{X}$ & $\mathbf{S}$ & $\mathbf{t}$ & sd & $\mathbf{P}$ \\
\hline \multirow{2}{*}{ Bilişsel Sinizm } & Evli & 184 & 10.11 & 2.46 & \multirow{2}{*}{3.35} & \multirow{2}{*}{303} & \multirow{2}{*}{$.001 *$} \\
\hline & Bekar & 121 & 11.06 & 2.32 & & & \\
\hline \multirow{2}{*}{ Davranışsal Sinizm } & Evli & 184 & 9.53 & 2.72 & \multirow{2}{*}{1.43} & \multirow{2}{*}{303} & \multirow{2}{*}{.153} \\
\hline & Bekar & 121 & 9.98 & 2.60 & & & \\
\hline \multirow{2}{*}{ Duyuşsal Sinizm } & Evli & 184 & 9.86 & 2.66 & \multirow{2}{*}{1.65} & \multirow{2}{*}{303} & \multirow{2}{*}{.100} \\
\hline & Bekar & 121 & 10.39 & 2.86 & & & \\
\hline \multirow{2}{*}{ Genel Sinizm Seviyesi } & Evli & 184 & 29.50 & 6.23 & \multirow{2}{*}{2.60} & \multirow{2}{*}{303} & \multirow{2}{*}{$.010^{*}$} \\
\hline & Bekar & 121 & 31.42 & 6.44 & & & \\
\hline
\end{tabular}
*p<,05

"Tablo-6'ya bakıldı̆̆ında, "Bilişsel Sinizm” alt faktörüne ilişkin spor işletmelerinde çalışanlardan evli olanların genel sinizm seviyeleri $(\bar{X}=10,11)$ ile bekar olanların genel sinizm seviyeleri $(\bar{X}=11,06)$ arasında $\mathrm{t}_{(303)}=3,35, \mathrm{p}=, 001<, 05$ 'e göre anlamlı farklılık olduğu görülmektedir. "Davranışsal Sinizm" alt faktörüne ilişkin spor işletmelerinde çalışanlardan evli olanların genel sinizm seviyeleri $(\bar{X}=9,53)$ ile bekar olanların genel sinizm seviyeleri $(\bar{X}$ $=9,98)$ arasında $\mathrm{t}_{(303)}=1,43, \mathrm{p}=, 153>, 05$ 'e göre anlamlı farklılık olmadığı görülmektedir. "Duyuşsal Sinizm” alt faktörüne ilişkin spor işletmelerinde çalışanlardan evli olanların genel sinizm seviyeleri $(\bar{X}=9,86)$ ile bekar olanların genel sinizm seviyeleri $(\bar{X}=10,39)$ arasinda $\mathrm{t}_{(303)}=1,65, \quad \mathrm{p}=, 100>, 05$ 'e göre anlamlı farklılık olmadığ Ölçeğinin geneline bakıldığında spor işletmelerinde çalışanlardan evli olanların genel sinizm seviyeleri $(\bar{X}=29,50)$ ile bekar olanların genel sinizm seviyeleri $(\bar{X}=31,42)$ arasinda $\mathrm{t}_{(303)}=2,60, \mathrm{p}=, 010<, 05$ 'e göre anlamlı farklılık olduğu görülmektedir. Bilişsel sinizm alt faktörü ile genel sinizm ölçeğinin genelinden elde edilen puanlar incelendiğinde çalışanlardan evli olanların sinizm seviyeleri, bekar olanların sinizm seviyelerine göre daha düşük olduğu ve bu farkın anlamlılık yarattığ 1 sonucuna ulaşılmaktadır.

Spor işletmelerinde çalışanların idari görevleri olup olmadıklarına göre genel sinizm seviyeleri arasında farklılık Tablo - 7' de verilmiştir. 
Tablo 7. Çalışanların idari görev durumlarına göre sinizm seviyelerindeki farklılı̆̆a ait ındependentsample (bağımsız örneklem) t-testi sonuçları

\begin{tabular}{|c|c|c|c|c|c|c|c|}
\hline Alt boyutlar & $\begin{array}{c}\text { İdari Görevlerinin } \\
\text { Olma Durumu }\end{array}$ & $\mathbf{N}$ & $\bar{X}$ & $\mathbf{S}$ & $\mathbf{t}$ & sd & $\mathbf{p}$ \\
\hline \multirow{2}{*}{ Bilişsel Sinizm } & Evet & 140 & 10.31 & 2.27 & \multirow{2}{*}{1.15} & \multirow{2}{*}{303} & \multirow{2}{*}{.252} \\
\hline & Hayır & 165 & 10.64 & 2.59 & & & \\
\hline \multirow{2}{*}{ Davranışsal Sinizm } & Evet & 140 & 9.52 & 2.68 & \multirow{2}{*}{1.10} & \multirow{2}{*}{303} & \multirow{2}{*}{.271} \\
\hline & Hayır & 165 & 9.86 & 2.67 & & & \\
\hline \multirow{2}{*}{ Duyuşsal Sinizm } & Evet & 140 & 9.61 & 2.79 & \multirow{2}{*}{2.69} & \multirow{2}{*}{303} & \multirow{2}{*}{$.008 *$} \\
\hline & Hayır & 165 & 10.45 & 2.66 & & & \\
\hline \multirow{2}{*}{ Genel Sinizm Seviyesi } & Evet & 140 & 29.45 & 6.56 & \multirow{2}{*}{2.06} & \multirow{2}{*}{303} & \multirow{2}{*}{$.040 *$} \\
\hline & Hayır & 165 & 30.95 & 6.15 & & & \\
\hline
\end{tabular}

“Bilişsel Sinisizm” alt faktörüne ilişkin spor işletmelerinde çalışanlardan idari görevi olanların genel sinizm seviyeleri $(\bar{X}=10,31)$ ile idari görevi olmayanların genel sinizm seviyeleri $(\bar{X}$ $=10,64)$ arasında $\mathrm{t}_{(303)}=1,15, \mathrm{p}=, 252>, 05$ 'e göre, "Davranışsal Sinizm" alt faktörüne ilişkin spor işletmelerinde çalışanlardan idari görevi olanların genel sinizm seviyeleri $(\bar{X}=9,52)$ ile idari görevi olmayanların genel sinizm seviyeleri $(\bar{X}=9,86)$ arasında $\mathrm{t}_{(303)}=1,10, \mathrm{p}=, 271>, 05$ 'e göre anlamlı farklılık olmadığı görülmektedir. "Duyuşsal Sinizm” alt faktörüne ilişkin spor işletmelerinde çalışanlardan idari görevi olanların genel sinizm seviyeleri $(\bar{X}=9,61)$ ile idari görevi olmayanların genel sinizm seviyeleri $(\bar{X}=10,45)$ arasında $\mathrm{t}_{(303)}=2,69, \mathrm{p}=, 008<, 05$ 'e göre anlamlı farklılık olduğu görülmektedir. Duyuşsal sinizm alt faktörü ile genel sinizm ölçeğinin genelinden elde edilen puanlar incelendiğinde çalışanlardan idari görevi olanların sinizm seviyeleri, idari görevi olmayanların sinizm seviyelerine göre daha düşük olduğu ve bu farkın anlamlılık yarattığı sonucuna ulaşılmaktadır.

Spor işletmelerinde çalışanların mesleki çalışma yıllarına göre genel sinizm seviyeleri Tablo 8' de verilmiştir. 
Tablo 8. Çalışanların mesleki çalışma yıllarına göre sinizm seviyeleri arasındaki farklılığa ait One-Way Anova sonuçları

\begin{tabular}{|c|c|c|c|c|c|c|c|}
\hline Alt boyutlar & Mesleki Çalışma Yılı & $\mathbf{N}$ & $X$ & $\mathbf{S}$ & $F(4-300)$ & $\mathbf{p}$ & $\begin{array}{r}\text { Post Hoc } \\
\text { (Tukey) }\end{array}$ \\
\hline \multirow{5}{*}{ Bilişsel Sinizm } & Bir Yildan Daha Az & 30 & 11.40 & 1.87 & \multirow{5}{*}{9.39} & \multirow{5}{*}{$.000 *$} & $1>3,1>4$ \\
\hline & $1-5$ Yil & 96 & 11.36 & 2.24 & & & $1>5$ \\
\hline & 6-10 Y1l & 68 & 10.35 & 2.26 & & & $2>3,2>4$ \\
\hline & $11-15$ Y1l & 60 & 9.32 & 2.25 & & & $2>5$ \\
\hline & 16 ve Üstü & 51 & 9.86 & 2.82 & & & \\
\hline \multirow{5}{*}{ Davranışsal Sinizm } & Bir Yıldan Daha Az & 30 & 9.73 & 2.74 & \multirow{5}{*}{1.58} & \multirow{5}{*}{.181} & \\
\hline & $1-5 Y_{11}$ & 96 & 9.92 & 2.47 & & & \\
\hline & 6-10 Yil & 68 & 10.16 & 2.69 & & & \\
\hline & $11-15 Y_{11}$ & 60 & 9.35 & 2.70 & & & \\
\hline & 16 ve Üstü & 51 & 9.10 & 2.90 & & & \\
\hline \multirow{5}{*}{ Duyuşsal Sinizm } & Bir Yıldan Daha Az & 30 & 11.03 & 2.36 & \multirow{5}{*}{4.83} & \multirow{5}{*}{$.001 *$} & \\
\hline & $1-5$ Yil & 96 & 10.76 & 2.67 & & & $1>4,1>5$, \\
\hline & 6-10 Yil & 68 & 9.90 & 2.58 & & & $2>5$ \\
\hline & 11-15 Yil & 60 & 9.32 & 2.90 & & & \\
\hline & 16 ve Üstü & 51 & 9.31 & 2.75 & & & \\
\hline \multirow{5}{*}{ Genel Sinizm Seviyesi } & Bir Yildan Daha Az & 30 & 32.17 & 5.75 & \multirow{5}{*}{6.09} & \multirow{5}{*}{$.000 *$} & \\
\hline & $1-5 Y_{11}$ & 96 & 32.04 & 5.97 & & & \\
\hline & 6-10 Y1l & 68 & 30.41 & 6.45 & & & $1>4$ \\
\hline & 11-15 Y1l & 60 & 27.98 & 5.73 & & & $2>4,2>5$ \\
\hline & 16 ve Üstü & 51 & 28.27 & 6.87 & & & \\
\hline
\end{tabular}

*p<,05 Kategoriler: Bir Y1ldan Daha Az=1, 1-5 Yı1=2, 6-10 Yıl=3, 11-15 Y11=4, 16 ve Üstü=5

"Davranışsal Sinizm" alt faktörüne ilişkin çalışanların mesleki çalışma yıllarına göre genel sinizm seviyeleri arasında $\mathrm{F}_{(4-300)}=1,58, \mathrm{p}=, 181>, 05$ 'e göre, anlamlı farklılık olmadı̆̆ görülmektedir "Bilişsel Sinizm" alt faktörüne ilişkin çalışanların mesleki çalışma yıllarına göre genel sinizm seviyeleri arasında $\mathrm{F}_{(4-300)}=9,39$, $\mathrm{p}=, 000<, 05$ 'e göre anlamlı farklılık olduğu görülmektedir.. "Duyuşsal Sinizm” alt faktörüne ilişkin çalışanların mesleki çalışma yıllarına göre genel sinizm seviyeleri arasında $\mathrm{F}_{(4-300)}=4,83$, $\mathrm{p}=, 001<, 05$ 'e göre anlamlı farkl1lık olduğu görülmektedir Genel sinizm ölçeğinin geneline ilişkin çalışanların mesleki çalışma yıllarına göre sinizm seviyeleri arasında $\mathrm{F}_{(4-300)}=6,09, \mathrm{p}=, 000<, 05$ 'e göre anlamlı farklılık olduğu görülmektedir. Bu anlamlı farklılık, bir yıldan daha az mesleki kıdeme sahip olan çalışanların genel sinizm seviyelerinin ( $\bar{X}=32,17$ ) ve "1-5 Y1l” mesleki kıdeme sahip olan çalışanların genel sinizm seviyelerinin ( $\bar{X}=32,04)$, “11-15 Y1l” mesleki kıdeme sahip olan çalışanların genel sinizm seviyelerinden ( $\bar{X}=27,98)$ büyük olmasından ve "1-5 Y1l” mesleki kıdeme sahip olan çalışanların genel sinizm seviyelerinin $(\bar{X}=32,04)$, “16 ve Üstü Yı1” mesleki kıdeme sahip olan çalışanların genel sinizm seviyelerinden $(\bar{X}=28,27)$ büyük olmasından kaynaklanmaktadır. 
Spor işletmelerinde çalışanların gelir değişkenlerine göre genel sinizm seviyeleri Tablo - 9’ da verilmiştir.

Tablo 9. Çalışanların gelir değişkenlerine göre genel sinizm ölçeğinin geneli ve alt faktörlerine ilişkin sinizm seviyeleri arasındaki farklılığa ait one-way anova sonuçları

\begin{tabular}{|c|c|c|c|c|c|c|c|}
\hline Alt boyutlar & Gelir Düzeyi & $\mathbf{N}$ & $X$ & $\mathbf{S}$ & $F(6-298)$ & $\mathbf{p}$ & Post Hoc (Tukey) \\
\hline \multirow{6}{*}{ Bilişsel Sinizm } & $0-1000 \mathrm{TL}$ & 36 & 11.61 & 2.07 & \multirow{5}{*}{$5.32 *$} & \multirow{5}{*}{$.000 *$} & \\
\hline & $1001-2000 \mathrm{TL}$ & 79 & 10.94 & 2.47 & & & $1>3$ \\
\hline & 2001-3000 TL & 87 & 10.08 & 2.50 & & & $1>4$ \\
\hline & $3001-4000 \mathrm{TL}$ & 72 & 9.75 & 2.20 & & & $2>4$ \\
\hline & 4001 ve Üstü & 31 & 10.90 & 2.52 & & & \\
\hline & $0-1000 \mathrm{TL}$ & 36 & 10.86 & 2.67 & \multirow{5}{*}{$4.02 *$} & \multirow{5}{*}{$.003^{*}$} & \\
\hline \multirow{4}{*}{$\begin{array}{l}\text { Davranışsal } \\
\text { Sinizm }\end{array}$} & $1001-2000 \mathrm{TL}$ & 79 & 10.25 & 2.25 & & & \\
\hline & 2001-3000 TL & 87 & 9.24 & 2.99 & & & $1>3$ \\
\hline & $3001-4000 \mathrm{TL}$ & 72 & 9.21 & 2.33 & & & $1>4$ \\
\hline & 4001 ve Üstü & 31 & 9.42 & 2.99 & & & \\
\hline \multirow{5}{*}{$\begin{array}{l}\text { Duyuşsal } \\
\text { Sinizm }\end{array}$} & $0-1000 \mathrm{TL}$ & 36 & 11.61 & 2.70 & \multirow{5}{*}{$7.22 *$} & \multirow{5}{*}{$.000 *$} & $1>3,1>4,1>5$ \\
\hline & $1001-2000 \mathrm{TL}$ & 79 & 10.61 & 2.43 & & & $2>4$ \\
\hline & $2001-3000 \mathrm{TL}$ & 87 & 10.03 & 3.01 & & & \\
\hline & $3001-4000 \mathrm{TL}$ & 72 & 9.00 & 2.43 & & & \\
\hline & 4001 ve Üstü & 31 & 9.48 & 2.49 & & & \\
\hline \multirow{5}{*}{$\begin{array}{l}\text { Genel Sinizm } \\
\text { Seviyesi }\end{array}$} & $0-1000 \mathrm{TL}$ & 36 & 34.08 & 5.20 & \multirow{5}{*}{$7.86^{*}$} & \multirow{5}{*}{$.000 *$} & $1>3,1>4,1>5$ \\
\hline & $1001-2000 \mathrm{TL}$ & 79 & 31.80 & 5.85 & & & $2>4$ \\
\hline & 2001-3000 TL & 87 & 29.36 & 6.68 & & & \\
\hline & $3001-4000 \mathrm{TL}$ & 72 & 27.96 & 5.83 & & & \\
\hline & 4001 ve Üstü & 31 & 29.81 & 6.63 & & & \\
\hline
\end{tabular}

*p<,05 Kategoriler: 0-1000 TL=1, 1001-2000 TL=2, 2001-3000 TL=3, 3001-4000 TL=4, 4001 ve Üstü=5

"Bilişsel Sinizm" alt faktörüne ilişkin çalışanların gelir düzeyine göre sinizm seviyeleri arasında $\mathrm{F}_{(4-300)}=5,32, \mathrm{p}=, 000<, 05$ 'e göre, "Davranışsal Sinizm" alt faktörüne ilişkin çalışanların gelir düzeyine göre sinizm seviyeleri arasında $\mathrm{F}_{(4-300)}=4,02, \mathrm{p}=, 003<, 05$ 'e göre, "Duyuşsal Sinizm" alt faktörüne ilişkin çalışanların gelir düzeyine göre sinizm seviyeleri arasında $\mathrm{F}_{(4-300)}=7,22, \mathrm{p}=, 000<, 05$ 'e göre anlamlı farkl1lık olduğu görüldü. Genel sinizm Ölçeğinin geneline ilişkin çalışanların gelir düzeyine göre sinizm seviyeleri arasında $F_{(6-}$ ${ }_{298)}=7,86, p=, 000<, 05$ 'e göre anlamlı farkl1lık olduğu görülmektedir. Bu anlamlı farklılık, " 0 1000 TL” gelir düzeyine sahip olan çalışanların sinizm seviyelerinin ( $\bar{X}=34,08)$, “2001-3000 TL" gelir düzeyine sahip olan çalışanların sinizm seviyelerinden ( $\bar{X}=29,36)$, "3001-4000 TL" gelir düzeyine sahip olan çalışanların sinizm seviyelerinden $(\bar{X}=27,96)$ ve "4001 ve Üstü TL" gelir düzeyine sahip olan çalışanların sinizm seviyelerinden $(\bar{X}=29,81)$ büyük olmasından ve "1001-2000 TL" gelir düzeyine sahip olan çalışanların sinizm seviyelerinin $(\bar{X}=31,80)$, “3001-4000 TL" gelir düzeyine sahip olan çalışanların sinizm seviyelerinden ( $\bar{X}=27,96)$ daha büyük olmasından kaynaklanmaktadır. 


\section{TARTIŞMA, SONUÇ ve ÖNERILER}

İşletmelerde personelin kuruma bağlılıklarının belirlenmesinde sinizm önemli bir kavram olarak karşımıza çıkmaktadır. Sinizm seviyesi ile ilişkili pek çok faktör vardır. Gelir durumu, eğitim seviyesi, örgütsel fonksiyonlar sinizmin göstergeleri arasında yer aldığı bildirilmiştir (Fero, 2005). Spor işletmelerinde çalışan personelin genel sinizm seviyelerini incelediğimiz araştırmada, demografik değişkenlerden yaş faktörünün duyuşsal ve bilişsel sinizmi etkilediği ve en yüksek 20-24 yaş arağında görüldüğü saptanmıştır. Çalışanlardan evli olanların bilişsel sinizm seviyelerinin bekar olanların sinizm seviyelerine göre daha düşük olduğu görülmüştür. Hemşireler üzerinde yapılan başka bir çalışmada sinizmin ortaya çıkışına yol açan en önemli faktörlerden işe yabancılaşma oranının bekar olan hemşirelerde evli olan hemşirelerden daha yüksek düzeyde olduğu görülmüştür (Ertekin ve Özmen, 2017). Ayrıca idari görevde olmayanların duyuşsal sinizm seviyelerinin daha yüksek olduğu, bilişsel ve davranışsal boyutta ise anlamlı bir fark olmadığı belirlendi. Bununla birlikte 1 yıldan daha az görev yapan personelin bilişsel ve duyuşsal sinizm seviyelerinin anlamlı daha fazla olduğu görüldü. Farklı bir çalışmada Öztürk ve Kahraman (2015) çalışma yılıyla birlikte sinizmin bilişsel ve duyuşsal boyutunun da arttı̆̆ını tespit etmişlerdir.

Bu sonuçlara göre;

- Mesleki çalışma yılı daha az ve yaşı genç olan kişilerin daha sinik olduğu sonucu doğrultusunda, işe yeni başlayan personel için oryantasyon programlarının yapılması,

- İdari görevde olan çalışanların sinizm seviyelerinin daha yüksek olması sonucunda, bu pozisyonda çalışan personel ile düzenli görüşmeler yapılması,

- İşletmelerde yöneticiler tarafından personelin beklentileri, istekleri, önerileri dikkate alınarak düzenlemeler yapılması, Yöneticilerin, örgütler açısından işten ayrılma niyeti, işe devamsızlık, örgüte bağlılık ve iş tatmini gibi örgütsel verimliliği etkileyen değişkenleri açıklamada katkısı olan sinizm ve tükenmişlik gibi istenmeyen çalışan tutumlarını ortadan kaldırmada pozitif bir çalışma iklimi yaratmaları (Çalışkan, 2015),

- İşletmelerin hizmet kalitelerini yükseltmek için sinizme neden olan sebepleri belirleyip, önlem alması,

- Özellikle hizmet işletmelerinin yoğun olduğu yerlerde sinizm ve duygusal tükenmişliğin işyerinde profesyonel davranışların azalmasına neden olduğu belirtilmektedir (Bakker ve ark., 2003). Bu görüş doğrultusunda tükenmişlik, sinizm ve profesyonel davranışlar ilişkisinin incelenmesine yönelik çalışma örneklemini genişleterek, yeni araştırmalar planlanabilir.

$\mathrm{Bu}$ araştırmanın en önemli kısıtlılığını, tek bir bölgede ve kısıtlı sayıda bir örneklem grubu ile gerçekleştirilmiş olması oluşturmaktadır. Çalışmanın yalnızca İstanbul ile sınırlı kalması, araştırmanın dar bir alanda yapıldığını gösterse de; spor alanında sinizm kavramı ile ilgili yapılacak diğer çalışmalara ışık tutması beklenmektedir. 
Ceyhun, S., Malkoç, N., Arslan, N. (2017). Özel spor işletmelerinde çalışan personelin genel sinizm düzeylerinin incelenmesi. Ulusal Spor Bilimleri Dergisi, 1(2), 12-26.

\section{KAYNAKÇA}

Abraham, R. (2000). Organizational cynicism: Bases and consequences: Generic, social, and general. Psychology Monographs, 126(3), 269-292.

Akman, G. (2013). Sağlık çalışanlarının örgütsel ve genel sinizm düzeylerinin karşılaştırılması. İstanbul Üniversitesi, Yükseklisans Tezi.

Andersson, L. M. (1996). Employee cynicism: An examination using a contract violation framework. Human Relations, 49 (11), 1395-1418.

Arslan, E. (2012). Süleyman Demirel Üniversitesi İktisadi ve İdari Bilimler Fakültesi akademik personelinin genel ve örgütsel sinizm düzeyi. Doğuş Üniversitesi Dergisi, 13 (1), 12-27.

Bakker, A.B., Demerouti, E., Boer, E. \& Schaufeli, W.B. (2003). Job demands and job resources as predictors of absence duration and frequency. Journal of Vocational Behavior, 62, 341-356.

Bernerth, J. B., Armenakis, A. A., Feild, H. S., \& Walker, H. J. ( 2007). Justice, cynicism, and commitment a study of important organizational change variables. The Journal of Applied Behavioral Science, 43(3), 309319.

Brandes, P., Castro, S., James, M.S.L., Martinez, A., Matherly, T., \& Ferris, G.H. (2008). The Interactive effects of job insecurity and organizational cynicism on work effort following a lay off. Journal of Leadership \& Organizational Studies, 14(3), 233-240.

Büyüköztürk, Ş., Çakmak, E.K., Akgün, Ö.E, Karadeniz, Ş., \& Demirel, F. (2012). Bilimsel araştırma yöntemleri. Ankara: Pegem.

Ceyhun, S. (2017). Spor işletmelerinde hizmet kalitesi. Germany: Lap Lambert Academic Publıshıng, Saarbrücken, ISBN 978-6202054034.

Çalışkan, S.C. (2015). Pozitif örgütsel davranış değiş̧kenleri ile yeni araştırma modelleri geliştirme arayışları: Pozitif örgütsel davranış değişkenlerinin işe adanmışlık, tükenmişlik ve sinizm üzerine etkileri ve bu etkileşimde örgütsel adalet algısının aracılık rolü üzerine bir Araştırma. DEÜ SBE Dergisi, 16 (3), 363-382.

Efilti, S., Gönen, Y. Ö., ve Ünal, Ö.F. ( 2008). Örgütsel Sinizm: Akdeniz Üniversitesi’nde görev yapan yönetici sekreterler üzerinde bir alan araştırması. 7. Ulusal Büro Yönetimi ve Sekreterlik Kongresi. 279-290.

Erdost, E., Karacaoğlu, K., ve Reyhanoğlu, M. (2007). Örgütsel sinizm kavramı ve ilgili ölçeklerin Türkiye 'deki bir firmada test edilmesi, XV. Ulusal Yönetim ve Organizasyon Kongresi Bildiri Kitab1. Sakarya Üniversitesi. 514-524.

Erkuş, A. (2013). Davranış Bilimleri Iç̧in Bilimsel Araştırma Süreci. Ankara: Seçkin.

Ertekin, P. ve Özmen, D. (2017). Bir üniversite hastanesinde çalışan hemşirelerde işe yabancılaşmayı yordayan değişkenlerin incelenmesi. Hemşirelikte Ĕ̆itim ve Araştırma Dergisi, 14 (1), 25-30.

Fero, H.C. (2005). Flow and cynicism in the workplace. Doctor of Philosophy, St Claremont: Claremont Graduate University.

Hocaniyazov, A. (2008). A ğırlama işletmelerinde örgütsel iklim ve liderlik. Yüksek Lisans Tezi, Dokuz Eylül Üniversitesi Sosyal Bilimler Enstitüsü, İzmir.

İmamoğlu, A.F. (1998). Toplam kalite yönetimi anlayışı açısından spor hizmetleri. Gazi Bed. Ĕgt Spor Bil. Der, $3(2), 51-62$.

Karasar, N. ( 2009). Bilimsel araştırma yöntemi. Nobel: Ankara.

Leiter, M.P. \& Schaufeli, W.B. (1996). Consistency of the burnout construct across occupations. Anxiety,Stress\&Coping, 9 (3), 229-243.

Mısırdalı Yangil, F., Baş, M., \& Aygün, S. (2014). Genel ve örgütsel sinisizm bağlamında otel çalışanları üzerine bir inceleme. Optimum: Ekonomi ve Yönetim Bilimleri Dergisi, 1(1), 99-112. 
Nair, P., \& Kamalanabhan, T. J. (2010). The Impact of cynicism on ethical intentions of Indian managers: The moderating role of their level of management. International Journal of Trade, Economics and Finance, 1(2), $155-159$.

Özdamar, K. (1999). Paket programlar ile istatistiksel veri analizi. Eskişehir: Kaan Kitabevi.

Öztürk, Z. ve Kahraman, N. (2015). Sağlık çalışanlarının örgütsel sinizm düzeyinin ölçülmesine yönelik bir araştırma. Electronic Journal of Vocational Colleges, Bürokon Özel Sayısl, 339-358.

Peng, Z., \& Zhou, F. (2009). The Moderating effect of supervisory conscientiousness on the relationship between employees social cynicism and perceived interpersonal justice. Social Behavior and Personality, 37 (6), 863864.

Simha A, Elloy D.F., \& Huang H.C. (2014). The Moderated relationship between job burnout and organizational cynicism. Management Decision, 52( 3), 482 - 504.

Tokgöz, N., ve Hakan, Y. (2008). Örgütsel Sinizm: Eskişehir ve Alanya'daki otel işletmelerinde bir uygulama. Anadolu Üniversitesi Sosyal Bilimler Dergisi, 8(2), 283-303.

Yücel, İ. ve Çetinkaya, B. (2015). Örgütsel sinizm ile örgütsel bağlılık arasındaki ilişki ve çalışanların yaşının bu ilişki üzerindeki etkisi- Bazen Hoşlanmasak da Kalmak Zorunda Olabiliriz!. Atatürk Üniversitesi Sosyal Bilimler Enstitüsü Dergisi, 19 (3), 247-271. 